\title{
Mhjournal
}

\section{Representaciones de España y Latinoamérica en producciones audiovisuales}

Eva Hernández Martínez | evhern01@ucm.es

Universidad Complutense de Madrid

Rosario Sánchez Vilela | rsanchez@ucu.edu.uy

Universidad Católica del Uruguay

Las representaciones que aparecen en las producciones audiovisuales de España y Latinoamérica constituyen el tema del presente monográfico. Nos proponemos identificar en él algunas de las imágenes que pueblan el universo imaginario en películas, series y otros formatos como el documental. Pero, ¿por qué dedicarse a buscar las representaciones que hacemos los hispanoparlantes de nosotros mismos? ¿Por qué escoger el audiovisual como objeto de análisis para esta tarea? En la realidad de las personas, para su relación con los otros, solo existe lo que encuentra representación. Es necesario aparecer ante la mirada de otros para que se produzca el reconocimiento y la diferencia, pero en tiempos de modernidad tardía y de relaciones desenclavadas (Giddens, 1997) las imágenes en los productos audiovisuales proveen -aunque no de manera excluyente- de cierto espacio de aparición, de recursos para elaborar el juicio y la opinión (Silverstone, 2010). Esto no quiere decir que lo otro, lo que no encuentra lugar en la representación, desaparezca de la subjetividad del individuo; nada más lejos, puede permanecer oculto e irrumpir de forma más o menos violenta en producciones artísticas y comunicativas. La representación es la manera por la que los seres humanos construimos un mundo en común, siempre cambiante, controversial, pero común. En las producciones audiovisuales, distintas percepciones de la realidad alcanzan expresión simbólica.

Este monográfico se propone explorar las representaciones de España y de Latinoamérica en distintas producciones audiovisuales: Mientras dure la guerra (Alejandro Amenábar, 2019), Patria (Aitor Gabilondo, 2020), Sitiados (Carmen Gloria López, 2015), La casa de las flores (Manolo Caro, 2018), Buenos Aires viceversa (Alejandro Agresti, 1996) y Secretos de lucha (Maiana Bidegain, 2007). Además, otro par de autores utilizan un corpus más amplio que incluye otros tantos títulos. Ofrece una amplia visión, incluyendo autores de más de ocho 
universidades distintas, que analizan cómo aparecen España, Chile, México, Argentina y Uruguay en diferentes realizaciones audiovisuales que circulan en un escenario global, en

diversos soportes mediáticos y plataformas. ¿Qué imágenes genera cada comunidad de sí misma? ¿Qué representaciones de su pasado y de su presente se hacen disponibles en estas producciones? ¿Cómo ha sido la representación de España y de Latinoamérica a lo largo de la historia de la creación audiovisual?

Ya sea la identidad española, la latinoamericana -como conjunto- o la de alguno de los países que integran el continente de América del Sur, se trata de revelar cómo estas producciones ponen a disposición del espectador -y del analista- imágenes que integrarán el repertorio de recursos para pensar esas identidades.

Muchos de los trabajos recogidos en este monográfico se fijan en producciones que narran sucesos relacionados con memorias pasadas que, de alguna forma, tratan de "amueblar nuestra memoria virtual del pasado" (González Requena, 2021). Es así que podemos confirmar que aquellos momentos -individuales o colectivos- que no pudieron ser completamente tramitados - o no encontraron expresión suficiente- afloran más tarde en producciones audiovisuales. Y no solo ocurre que los artistas escogen representar estos momentos, sino que luego acaparan la atención de la audiencia, críticos, analistas... para ser nuevamente repensados desde distintas perspectivas.

En estos artículos se evidencia cómo la representación del trauma del pasado histórico-político sirve a pueblos, naciones y sujetos, para rearticular eventos traumáticos pasados. Por ejemplo; la Guerra Civil española, la actividad del grupo terrorista E.T.A en España, el drama de la conquista española en América, el golpe de estado de 1976 en Argentina o la dictadura militar uruguaya (1973-1984) son algunos de los sucesos que aparecen retratados en estos trabajos. Las representaciones del pasado constituyen recursos para deliberar sobre él, para procesar heridas, para darle un lugar en el presente y en la memoria colectiva (Sánchez Vilela, 2016). Este compendio contiene estudios que analizan o reflexionan sobre producciones audiovisuales de ocho países distintos y aparecen agrupados en tres bloques temáticos.

El primer bloque incluye tres propuestas sobre producciones audiovisuales donde se aborda la representación de España; Javier González Torres recoge en su análisis de la película Mientras dure la Guerra la visión del director Alejandro Amenábar sobre el comienzo de la Guerra Civil española entremezclada con la vida del filósofo Miguel de Unamuno; Ana Quiroga Álvarez interroga a la serie de HBO Patria y la representación de las mujeres vascas alrededor del conflicto de ETA, ahondando en las fracturas sociales y políticas de la sociedad vasca; Antonio Terrón Barroso analiza la representación de los personajes españoles -coincidentes con los arquetipos de Carmen y Don Juan-incluidos en veinte títulos subvencionados por España y rodados en inglés (coproducidos junto a Reino Unido y/o Estados Unidos).

El segundo bloque aparece como transición entre el primero y el tercero; Juan Francis- 
co Gutiérrez Lozano y Ashley Jáñez González presentan, mediante un análisis de contenido, una revisión de las series de ficción y documentales latinoamericanos en los catálogos de Netflix y HBO para España.

Por último, en el tercer bloque se incluyen aquellos trabajos que abordan la representación de distintos países de América del Sur; Lorena Antezana y Consuelo Ábalos dedican su artículo a desmontar mitos en relación a la Colonia con la primera temporada de Sitiados de fondo; Gabriel Domínguez Partida presenta un análisis textual de la segunda temporada de La Casa de las flores, donde explora la representación de la familia mexicana y las identidades LGTBIQ en México; Patricia Delponti y Carmen Rodríguez Wangüemert analizan la película precursora de las posteriores tendencias audiovisuales latinoamericanas, Buenos Aires Viceversa, una aportación en tránsito entre el documental y la ficción con Argentina como escenario; Natalia Martínez Pérez y Sonia Dueñas Mohedas rescatan el documental

Secretos de Lucha para mirar de cerca el conflicto y el trauma generados por la dictadura uruguaya a partir de testimonios y la restauración de las memorias de una nueva generación, los hijos de los migrantes uruguayos.

Cada uno de los artículos ofrece una mirada particular sobre temas y problemas que todavía son objeto de dilucidación. Lejos de cerrar el debate, se proponen como apertura a nuevas preguntas.

\section{Referencias}

Giddens, A. (1997). Modernidad e identidad del yo. Barcelona: Península.

González Requena, J. (2021). El Fondo Paranoico que atosiga a España. En J. M. López-Agulló y N. Parejo (Eds.), Estructura y análisis del audiovisual en España y Latinoamérica (pp. 3-15). Madrid: Fragua

López-Agulló Pérez-Caballero, J.M. y Hernández-Martínez, E., (2021). Representación de España en las películas españolas más taquilleras desde el año 2006 al 2015. En M.I. Menéndez Menéndez, y E. De la Cuadra (Eds), Análisis de la comunicación aplicada: artes, narrativas y medios en España y Latam. Madrid: Fragua.

Silverstone, R. (2010). La moral de los medios de comunicación. Sobre el nacimiento de la polis de los medios. Buenos Aires: Amorrortu.

Sánchez Vilela, R. (2016). La ficción televisiva como recurso para la deliberación sobre el pasado. Luciérnaga Comunicación, 8 (16), 38-47. 
MHJournal Vol. 12 (2) | Año 2021 - Prólogo - Páginas 287 a 290 - mhjournal.org

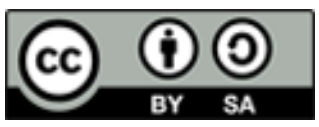

Licencia Creative Commons

Miguel Hernández Communication Journal mhcj.es

\section{Cómo citar este texto:}

Eva Hernández Martínez \& Rosario Sánchez Vilela (2021): "Representaciones de España y Latinoamérica en producciones audiovisuales", en Miguel Hernández Communication Journal, Vol. 13, páginas 287 a 290 Universidad Miguel Hernández, UMH (Elche-Alicante). DOI: 10.21134/mhjournalv12i1424 